\title{
Statistical Analyses of the Sea Breeze Pattern in Relation to General Weather Conditions
}

\author{
By Hiroshi Yoshikado \\ National Research Institute for Pollution and Resources, \\ Onogawa, Yatabe-machi, Ibaraki 305, Japan \\ (Manuscript received 15 August 1980, in revised form 9 October 1980)
}

\begin{abstract}
In order to investigate the variety of the sea breeze pattern, surface wind data in three areas in Japan were analysed statistically. In the criteria for the occurrence of the sea breeze, the direction of the synoptic-scale pressure gradient is an important factor as well as its intensity and the strength of land heating. Furthermore, the sea breeze patterns, which vary from day to day even at the same point, are shown to be influenced systematically by the geostrophic wind direction.
\end{abstract}

\section{Introduction}

The land and sea breeze have been investigated by many authors as one of the typical phenomena of local meteorology. Their thermodynamic processes contain various problems of theoretical interest. The land and sea breeze are in close connection with air pollution at coastal areas. Especially, since the sea breeze grows during the day in the warm seasons, its features such as the onset time, the velocity of inland penetration, the variations of wind speed and direction, etc. dominate the behaviors of photochemical pollutants. With such circumstances observational studies of the sea breeze have also been executed actively.

However, not many efforts have been made to compare the extensive results, to find their relative situations, and to understand the universal mechanisms of the sea breeze, if any. Surely the sea breeze is a very local phenomenon, and its growing and decaying pattern is different at every area because of the differences of latitude, sea temperature, topography, and other circumstances. It must be very difficult to discuss the sea breezes observed at various regions within one category.

As well, even at the same place, the sea breeze pattern varies considerably from day to day. Causes and fashions of the variety might be alike anywhere. Considering the basic mechanism of the sea breeze, it can be easily seen that the sea breeze becomes stronger with the amount of land heating or insolation. We can guess also that strong general wind has some influence on the sea breeze. The relations between general wind and the sea breeze was discussed by some early investigators. Wexler (1946) stated as general remarks that the onset time of the sea breeze is later under offshore gradient flow than in calm condition, and that when the gradient flow becomes stronger, the sea breeze does not occur but that the offshore gradient flow is reduced. Under onshore gradient flow the land heating is suppressed, so the sea breeze is recognized only as a little increase of the onshore gradient flow. Lyons (1972) analysed the lake breeze on Lake Michigan around Chicago in relation to general pressure field using massive data for three years' summer months. As a result, distinct tendency for lake breeze occurrence was found under northwesterly geostrophic wind which blows with the lake on the left-hand side. Furthermore, Lyons tried to forecast the lake breeze by means of the "lake breeze index" $V_{g}{ }^{2} / C_{p} \Delta T$ originally proposed by Biggs and Graves (1962), where $V_{g}$ is the geostrophic wind speed calculated from the contour interval of the surface weather map, $\Delta T$ the difference of the daily maximum air temperature at an inland site and the lake water temperature, $C_{p}$ the specific heat of air at constant pressure. It was hindcasted with each 
probability higher than $80 \%$ that the lake breeze cccurs when the index value is less than 10.0 and does not occur when larger than 10.0. In Japan several descriptions are found on the relationship between the sea breeze patterns and the pressure distributions. Sahashi (1978) classified the sea breeze on the Seto Inland Sea area into two types. At Okayama, where the shoreline is roughly in the east-west direction with the land on the north side and a small hilly land mass just on the south, the sea breeze days are divided by their wind direction into SW case and SE case. When the westerly wind aloft is stronger, the SW sea breeze is more frequent.

In the field of theoretical studies also the relation between such external conditions as land heating or general wind and the sea breeze has been investigated. According to the linear theories, as Haurwitz (1947) and Defant (1951), the maximum velocity of the sea breeze is in proportion to the amplitude of the land temperature or that of the pressure gradient, though their formulations have some deficiencies in the treatment of friction and heat conduction and disregard of advection. Haurwitz considered the effects of the general wind, too. The result represents that the hodograph removes to some extent down the geostrophic wind and to the low pressure side at the same time. In other words, the sea breeze appears as overlapped with a fraction of general wind. Walsh (1974) solved a linear system and found the criterion of $\Delta T$ to give a positive onshore wind i.e. the sea breeze against the contrary basic current, the result of which supports Biggs and Graves' idea. Since Estoque (1962) the influence of general wind on the sea breeze has been investigated using nonlinear numerical models. In case of Estoque's study the solutions under the general wind at $5 \mathrm{~m} \mathrm{sec}^{-1}$ in four directions are compared with that for calm condition. The results coincide with Wexler's description as a whole. Pielke (1974) composed a three-dimensional numerical model of the sea breeze over south Florida, and examined the effects of general wind at $6 \mathrm{~m} \mathrm{sec}^{-1}$ in directions SW and SE. The results well represent the observed characteristics that in every case the sea breeze on the upstream-side coast regarding the general wind is more prominent than that on the other side.

The observational and theoretical studies mentioned above do not give inconsistent conclusions. In short, it seems that under a moderate general wind the sea breeze appears with a frac- tion of the general wind added. But these conclusions are limited to qualitative appreciations. By means of numerical models it is difficult to deduce general conclusions from the solutions under some specified geostrophic winds. Concerning the field of observation there have not been presented enough data to compare with the theoretical results. For example, Walsh's study is limited to the offshore geostrophic wind case. Biggs and Graves' analyses and Lyons' do not take the geostrophic wind direction explicitly into account.

In the present work, in addition to the problem whether the sea breeze occurs or not in various conditions, the day-to-day irregularity of the sea breeze pattern is to be analysed in relation to general weather conditions such as the pressure field and the amount of land heating. The statistical method using the extensive data taken by the air monitoring stations is basically after the work of Kitabayashi (1976), which however didn't discuss the effect of general weather condition.

\section{Data and method of analyses}

\subsection{Studied areas and period}

Three areas are selected to analyse its sea breeze characteristics. They are the coastal areas of (A) Akita Bay, (B) Senday Bay, and (C) the Harimanada Sea centering around Himeji City. The maps of these areas are shown in Fig. 1. Their locations in whole Japan are known by referring to Fig. 3. These areas have a gently curved simple shoreline and a plain $10 \mathrm{~km}$ or more in depth from the shore, so that the sea breezes there are supposed to be free from special effects of topography. Unique features of each area are as follows.

(A) Akita area, facing the Japan Sea, has much snow in winter, so the sea breeze at Akita has not been paid much attention to, but its probability of occurrence is not small in warm seasons. Concerning the topography, the existence of Oga Peninsula should be taken into consideration for the northern part of the area. On the east of the Akita Plain is a mountainous region the highest part of which is near $1200 \mathrm{~m}$ above the sea level, and the plain is extended in the southeast direction along the Omono River.

(B) Sendai area faces the Pacific Ocean. The arrangement of land and sea is symmetrical in Sendai and Akita. But in case of Sendai, on the west of the area a mountainrange higher than $1000 \mathrm{~m}$ stretches north to south, and the plain 


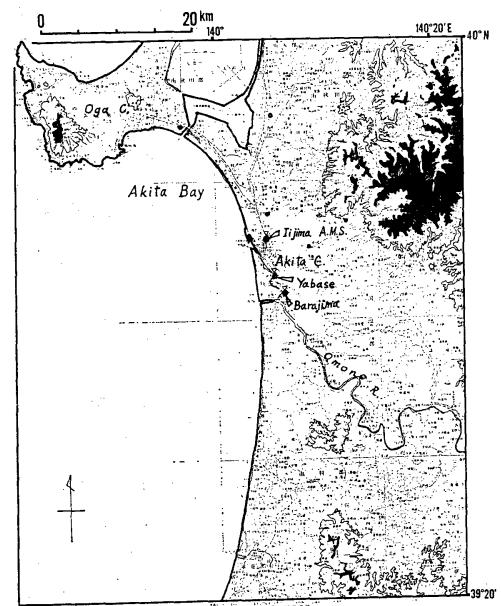

(A)

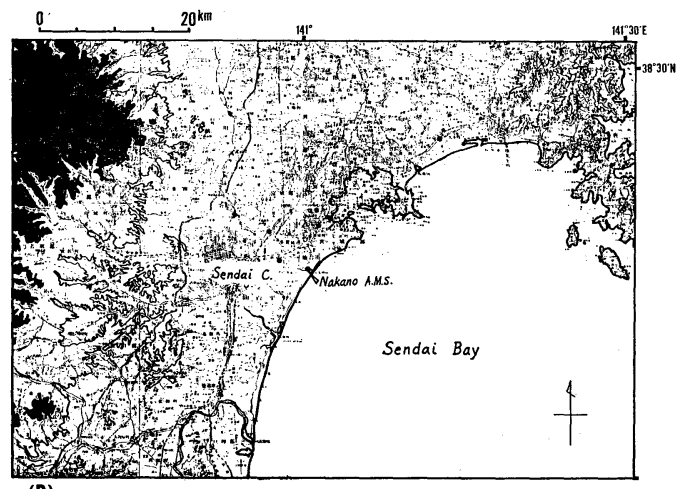

(B)

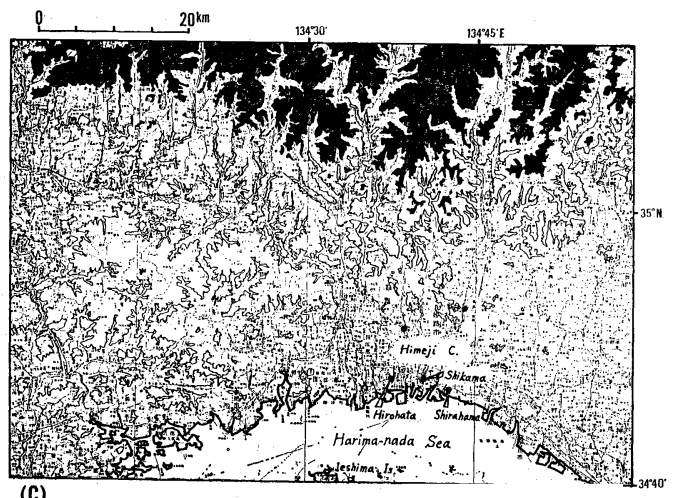

Fig. 1 Topography map around the studied areas. (A) Akita, (B) Sendai, and (C) Himeji area. Thin contours indicate $200 \mathrm{~m}$, and the shaded areas above $500 \mathrm{~m}$.

parallel to this is extended deep to the north from the northern shore of Sendai Bay.

(C) Himeji area is situated at a lower latitude than the former two, and has a mild climate characteristic in the inland-sea regions. In the neighborhood of Himeji City there spreads hilly terrain with $200-300 \mathrm{~m}$ undulation, while there is not a marked peak.

In these three areas networks of air quality monitoring stations had been established and their meteorological data were available.

The examined period is commonly one year from April 1, 1975 to March 31, 1976.

\subsection{Selection of sea breeze days}

For the judgment whether the sea breeze did occur or not on each day, mostly the surface wind data are used. The purpose of this judgment is to pick on roughly such days on which the wind record is endowed with ordinary sea breeze-like variations. The selected sea breeze days are, in the next step, examined regarding the relations with external conditions.

The surface wind data at the air monitoring stations are $10 \mathrm{~min}$ averaged, every one hour records in the standard wind directions of $2 \pi / 16$ width each and $0.1 \mathrm{~m} \mathrm{sec}^{-1}$ unit, while the wind speed less than $0.5 \mathrm{~m} \mathrm{sec}^{-1}$ is dealt with as calm, that leads inaccuracy to some extent.

The judging flow chart in case of Akita is shown in Fig. 2. According to this chart every

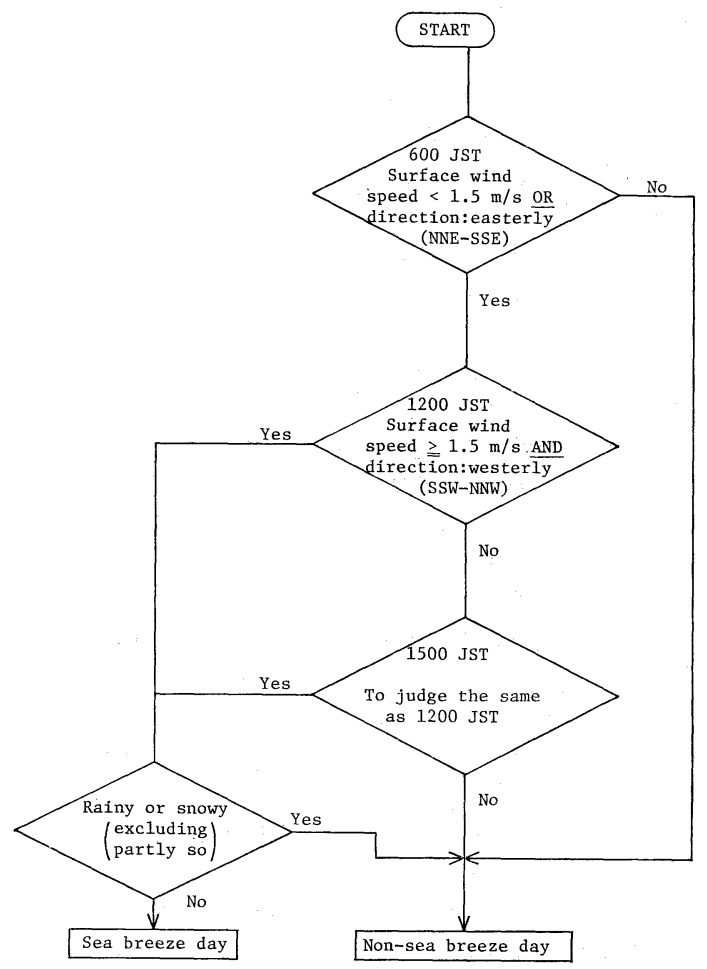

Fig. 2 Judging flow chart to select sea breeze days for Akita area. 
Table 1. Wind speed and direction standards for sea breeze day.

\begin{tabular}{|c|c|c|c|}
\hline Area & (A) Akita & (B) Sendai & (C) Himeji \\
\hline $\begin{array}{l}\text { Representative } \\
\text { stations }\end{array}$ & $\begin{array}{l}\text { Yabase, Barajima } \\
\text { and Iijima }\end{array}$ & $\underset{\text { (Kokusetsu**) }}{\text { Nakano }}$ & $\begin{array}{c}\text { Shikama, Shirahama } \\
\text { and Hirohata }\end{array}$ \\
\hline For $600 \mathrm{JST}$ & $\begin{array}{c}3 \text { point average }<1.5 \mathrm{~m} / \mathrm{s} \\
\text { or } \\
\text { every point NNE-SSE* }\end{array}$ & $\begin{array}{l}<1.5 \mathrm{~m} / \mathrm{s} \\
\quad \text { or } \\
\mathrm{SW}-\mathrm{NE}^{*}\end{array}$ & $\begin{array}{c}\text { every point } \\
\left(>1.5 \mathrm{~m} / \mathrm{s} \text { or } \mathrm{NW}-\mathrm{E}^{*}\right)\end{array}$ \\
\hline $\begin{array}{l}\text { For } 1200 \text { or } \\
1500 \text { JST }\end{array}$ & $\begin{array}{c}3 \text { point average } \geqq 1.5 \mathrm{~m} / \mathrm{s} \\
\text { and } \\
\text { every point } \mathrm{SSW}-\mathrm{NNW}^{*}\end{array}$ & $\begin{array}{l}\geqq 2.0 \mathrm{~m} / \mathrm{s} \\
\quad \text { and } \\
\mathrm{E}-\mathrm{SSW}^{*}\end{array}$ & $\begin{array}{c}3 \text { point average } \geqq 1.5 \mathrm{~m} / \mathrm{s} \\
\text { and } \\
\text { every point } \mathrm{SE}-\mathrm{W}^{*}\end{array}$ \\
\hline
\end{tabular}

*) clockwise

**) in case of data lack at Nakano

day in the studied period is classified into sea breeze day or non-sea breeze day. To the other two areas the same flow chart is applied but some standard values are different as shown in Table 1 . The ranges of these standards for wind speed and direction are not unique, being chosen so as to be suited well to subjective judgment. Some other ranges could be taken if, for example, the position or altitude of the measuring stations was different. The last item in the flow chart relating the general weather is added in order to satisfy the basic conception of the sea breeze. This item is fairly meaningful because the judgment by wind condition only might easily mistake passing cold fronts for the sea breeze. As the weather data, the observation diaries of neighboring meteorological observatories are referred to.

\subsection{Other data}

i) Index of the general pressure field

Some adequate index of the general pressure distribution is to be defined to examine how it affects the sea breeze development. For that purpose, the surface pressures at three points surrounding the studied area at 900 JST are used. The pressure gradient obtained from them is transformed into the corresponding geostrophic wind (denoted symbolically as $V_{g}$ hereafter for simplicity), which is adopted as the index. For Akita and Sendai $V_{g}$ is composed of the vectors for respective three triangles in Fig. 3. For Himeji there is some difficulty in deciding the region in which the general pressure gradient is to be computed. It seems that sometimes a pressure field peculiar to the inland-sea region is quite different from one for a larger triangle composed of points on the outer sea coasts. The index value for the inland-sea region is taken in this study.

The air density, the variation of which is small enough compared with that of the pressure gradient, can be regarded as a constant, its value at $0^{\circ} \mathrm{C}, 1 \mathrm{~atm}$. Then the geostrophic wind speed $V_{g}\left(\mathrm{~m} \mathrm{sec}^{-1}\right)$ and the horizontal pressure gradient $\partial p / \partial n\left(\mathrm{mb} \mathrm{km}^{-1}\right)$ has the relation

$$
V_{g}=k \frac{\partial p}{\partial n}
$$

The value of a constant $k$ varies with latitude, and is 825 for Akita, 862 for Sendai, and 925 for Himeji.

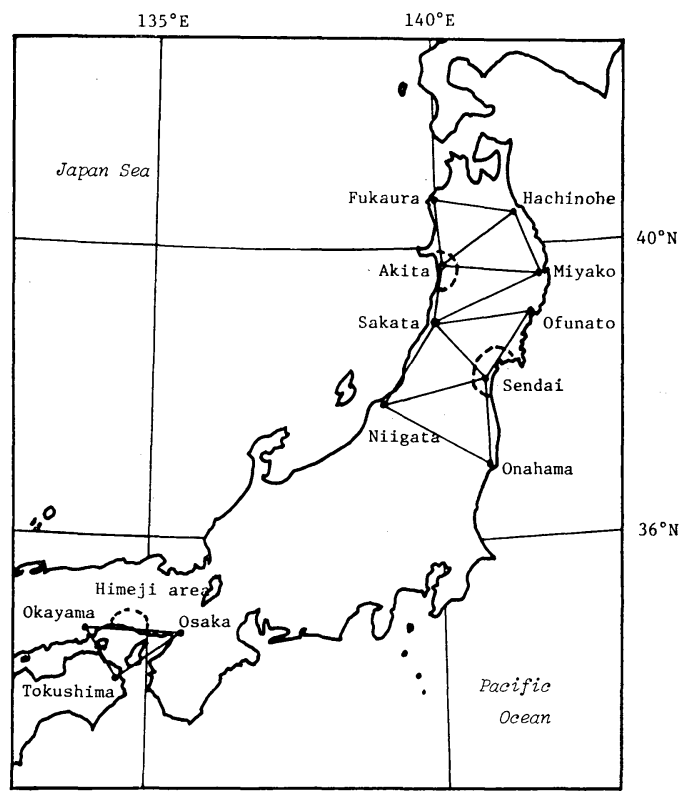

Fig. 3 Reference points for calculation of the general pressure gradient. 
Table 2. Correlation of the accumulative insolations before 1200 JST at the adopted site and a site neighboring to the studied area (number of days).

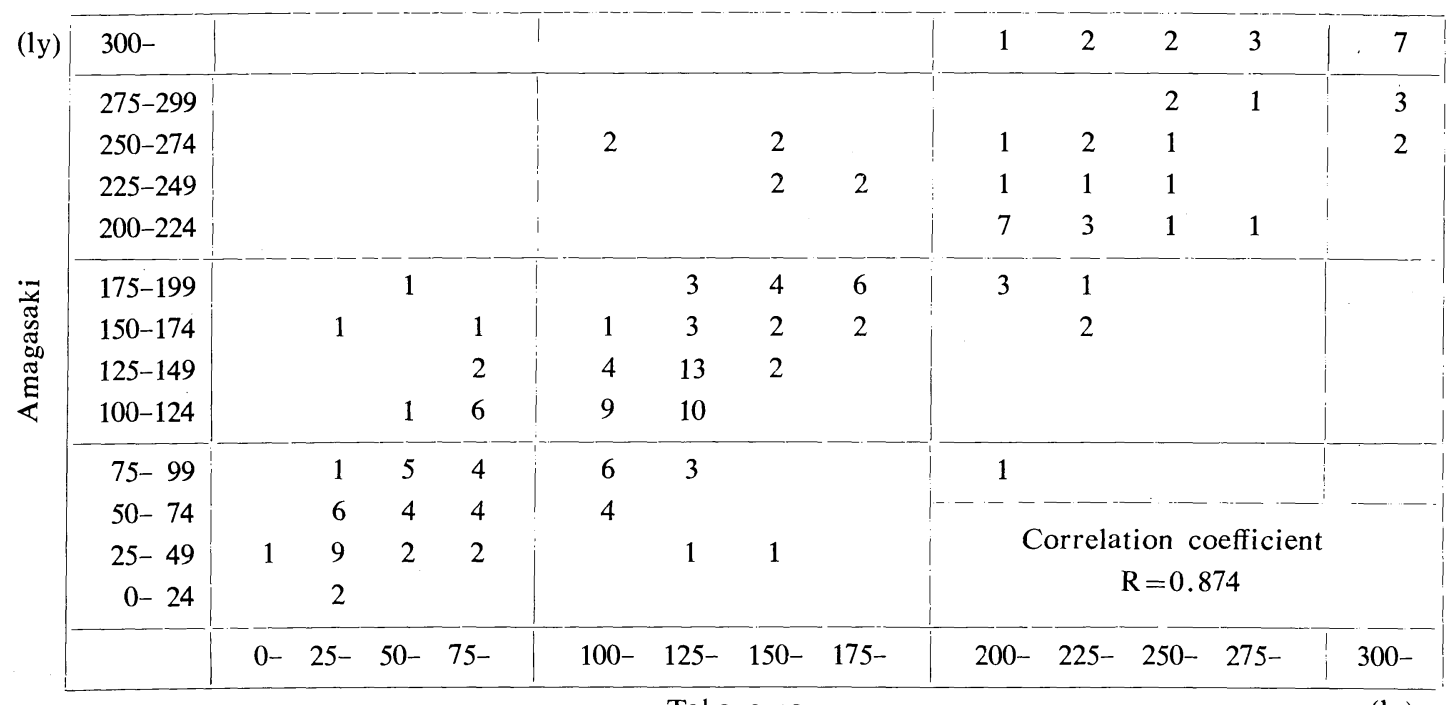

Note i) The adopted observing site Amagasaki is about $70 \mathrm{~km}$ east of the center of the studied area, and the compared site Takayama is $28 \mathrm{~km}$ west of the center.

ii) The period when the data are acquired at both sites and included in the table is 6 months: Jul., Aug., Oct., Dec., 1975, Jan. and Mar., 1976.

ii) Index of the amount of land heating

The temperature difference between the sea surface and the land air at an adequate inland point might be a good index of thermal condition governing the sea breeze development. However, there is no routine observation of the temperature at sea, and very few data are available. On the other hand, the land air temperature is affected by the sea breeze itself, so the observation point must be sought in the outer area where the sea breeze does not reach. But in such a mountainous and inhomogeneous country as Japan, it is difficult to select an observation point representative of the studied area. Therefore, in the present work the amount of insolation, which is closely connected with the land temperature increase after sunrise (e.g. appendix of Yoshikado, 1978) and besides not affected by the sea breeze, is adopted as the index. According to a presumption that the strength of insolation mainly during the morning hours governs the sea breeze development, the accumulative insolation before 1200 JST is taken as the basic index of the amount of land heating for each day.

The used data are due to the Akita Local Meteorological Observatory for Akita area, and to the Sendai District Meteorological Observatory for Sendai area. For Himeji routine observation data are not found in the area during the examined period, so the data taken at a site about $70 \mathrm{~km}$ east of the area are used. These data have been verified to coincide fairly well with those samples measured at a site closer to the area (see Table 2).

Hourly air temperature at the Akita Local Meteorological Observatory is also referred to for Akita area.

\section{Results}

\subsection{Distribution of sea breeze days}

Month-to-month variation of the number of sea breeze days for Akita is shown in Fig. 4. The accumulative insolation before $1200 \mathrm{JST} Q_{A M}$ is divided into five ranks and the frequencies of each rank are shown too in the figure. The days $Q_{A M}$ exceeds 250 ly appear only in April to September. The sea breeze days in the warm seasons nearly correspond in number to the days $Q_{A M} \geqq 250$ ly or $200 \mathrm{ly}$. These situations are common to the other two areas.

Every sample of the sea breeze days and nonsea breeze days for Akita is plotted in relation to $Q_{A M}$ vs. $V_{g}$, shown in Fig. 5. A remarkable feature is that the sea breeze days indicated by squares gather under a line passing the origin. That is, the sea breeze occurs the more frequently 


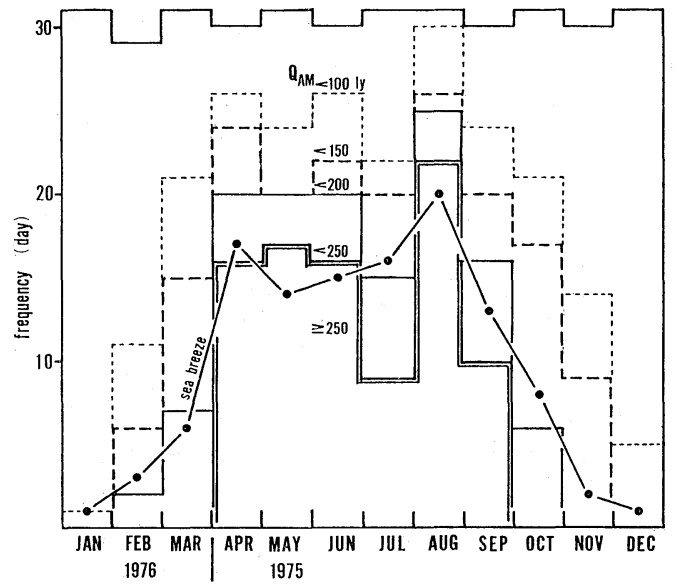

Fig. 4 Numbers of the sea breeze days in Akita area, with numbers of the days separated by the $Q_{A M}$ ranks.

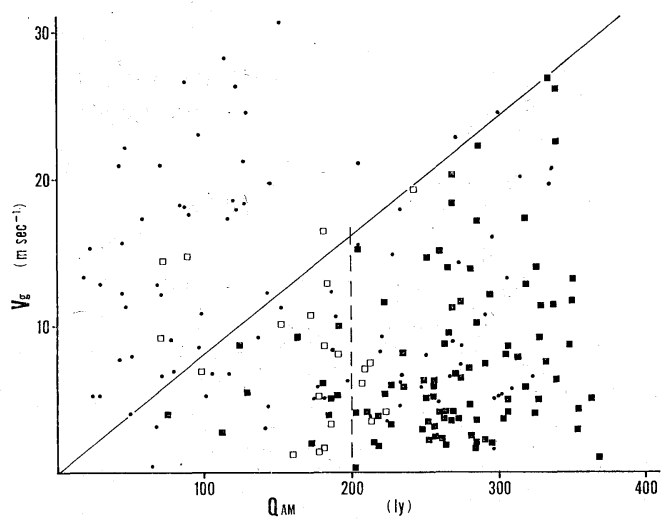

Fig. 5 Distribution of the sea breeze days (Apr.-Sept.: $\square$, Oct.-Mar.: $\square$ ) and non-sea breeze days (only Apr.-Sept. indicated by dots) in relation to $Q_{A M}$ and $V_{g}$ speed for Akita area.

as the insolation is stronger and the pressure gradient is smaller. At the same time, it is noteworthy that even in the region where the sea breeze frequently appears, non-sea breeze days are also distributed. Furthermore, the sea breeze days on which $Q_{A M}<160$ ly proved, through detailed inspection, to be short of essential features as the sea breeze. For example, the land air temperature is very low, the temperature rise during the morning is small, or the wind direction change between early morning and afternoon is not distinct on those days. Therefore, considering some further reliability in the aspect of heating amount, mainly the days on which $Q_{A M} \geqq$ 200 ly are analysed hereafter.
In case of Sendai and Himeji, the number of sea breeze days on which $Q_{A M}<2001 \mathrm{y}$ is larger than in Akita. Moreover many of those days have a fairly strong $V_{g}$. For these areas the days on which $Q_{A M}<200$ ly are excluded from the following analyses as well.

\subsection{Geostrophic wind direction and sea breeze probability}

According to Fig. 5 it seems that $Q_{A M} \geqq 2001 \mathrm{y}$ is the sufficient condition in the thermal aspect for the sea breeze occurrence, but some non-sea breeze days also satisfy this condition. Fig. 6 is contrived to investigate this inconsistency by regarding the $V_{g}$ direction. It can be seen first that every area has a predominant $V_{g}$ direction. For example, fairly strong $V_{g}$ 's are mostly northerly or southerly in Akita. This direction seems to coincide with the macroscopic direction of the coastline. In other words, isobars over these areas tend to be parallel to the coastlines, at least on fine days in warm seasons.

Secondly, each distribution of the sea breeze and non-sea breeze days in Fig. 6 is suggestive. In case of Akita where the land lies on the east, under the easterly offshore $V_{g}$ the sea breeze occurs with a relatively low probability (0.49), and under the westerly onshore $V_{g}$ it occurs with a high probability $(0.80)$. Evidently the $V_{g}$ direction is one of governing factors for the sea breeze growth. In case of Sendai the sea breeze is suppressed distinctly under the northerly $V_{g}$. As shown later, the sea breeze in Sendai blows from the south, so the northerly $V_{g}$ is opposite to it. The probability of the sea breeze occurrence is 0.48 under northerly $V_{g}$, and 0.86 under southerly $V_{g}$. In Himeji the easterly $V_{g}$ is very predominant, and the sea breeze occurs with a high probability under that situation. The number of the days with the $V_{g}$ other than the easterly one is so small that it is difficult to find any characteristics concerning to the sea breeze occurrence.

\subsection{Hodographs of the sea breeze days}

Not only the probability of the sea breeze occurrence but also the patterns of the wind variation on the sea breeze days are influenced by the $V_{g}$ direction. Fig. 7 shows the mean hodographs on the sea breeze days in Akita, grouped by the $V_{g}$ directions with $90^{\circ}$ width each. Days of the easterly $V_{g}$ are very few and ignored. The observing station Yabase is about $3 \mathrm{~km}$ east of the coastline. The patterns of the hodographs are different from one another, while 


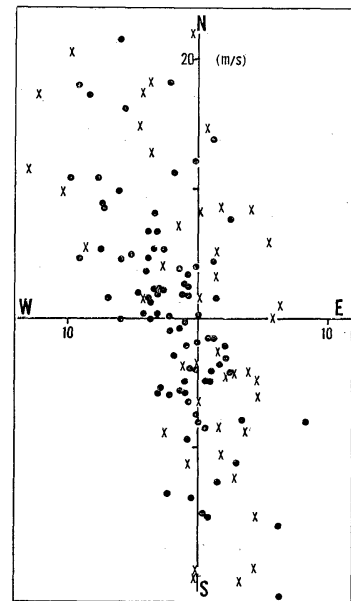

(A)

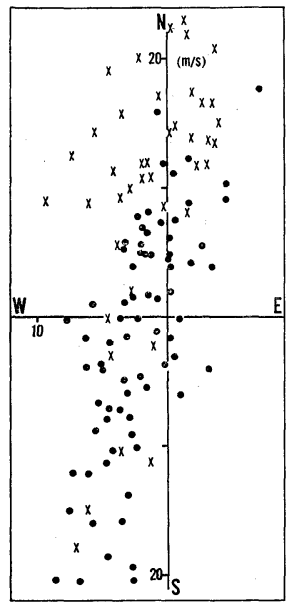

(B)

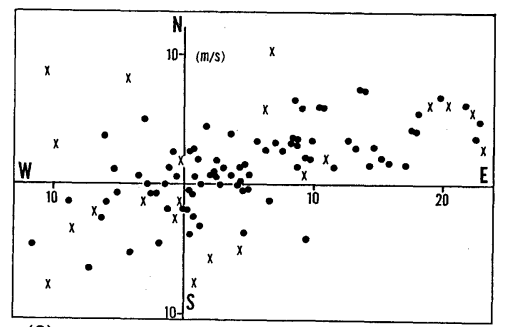

(C)

Fig. $6 V_{g}$ distributions on the days $Q_{A M} \geqq 200$ ly for (A) Akita, (B) Sendai, and (C) Himeji area. The distance and direction from the origin to each symbol represent the $V_{g}$ speed and direction respectively. Dots are for sea breeze day and crosses for nonsea breeze day.

they are similar for two classes of the $V_{g}$ speed in the same $V_{g}$ direction. It is difficult to represent exactly the difference of the hodograph patterns, but it seems that the position of any hodographs compared with the others removes to the right of the $V_{g}$ direction, that is, to the low pressure side. Actually, the daily average of the east-west component of the hodograph are 0.6 and $1.3 \mathrm{~m} \mathrm{sec}^{-1}$ westerly under the northerly $V_{g}$ with speed 1anges $0-10$ and $10-20 \mathrm{~m} \mathrm{sec}^{-1}$ respectively, and on the other hand they are 0.1 and $0.8 \mathrm{~m} \mathrm{sec}^{-1}$ easterly under the southerly $V_{g}$ with the same speed ranges. Corresponding to this difference, the onset time of the sea breeze, namely the time when the surface wind direction changes from easterly to westerly, is about 900 JST under the northerly $V_{g}$ in contrast with about 1100 JST under the southerly $V_{g}$. Under the westerly $V_{g}$, the averaged north-south component of the hodograph has a larger southerly value $0.8 \mathrm{~m} \mathrm{sec}^{-1}$ than under the other two, 0.5 under southerly and $-0.3 \mathrm{~m} \mathrm{sec}^{-1}$ under northerly $V_{g}$ in the same speed range.

The hodographs for Sendai are shown in Fig. 8. The observing station Nakano is at the east end of Sendai and near seashore. There is not a notable difference among the hodographs. In detail, however, the easterly component of the hodograph is fairly larger under the southerly $V_{g}$ than under the northerly $V_{g}$, to be sure, only at the mature stage of the sea breeze, around 1000-1500 JST. These deformations of hodograph are in the same sense as in Akita.
The westerly $V_{g}$ case seems to have only neutral feature in Sendai, which may be connected with
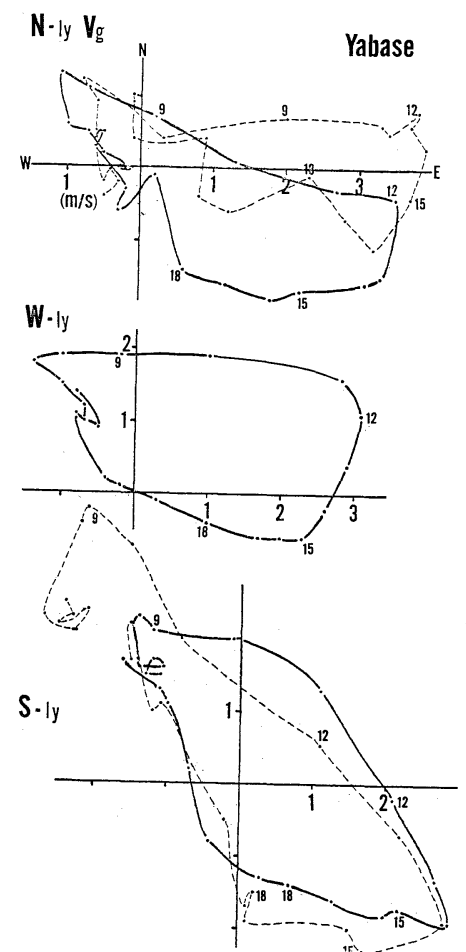

Fig. 7 Sea breeze hodographs averaged partially by the $V_{g}$ direction for Akita. $Q_{A M} \geqq 2001 y$. Thick lines are for $V_{g}<10 \mathrm{~m} \mathrm{sec}^{-1}$, and thin broken lines for $10 \leqq V_{g}<20 \mathrm{~m} \mathrm{sec}^{-1}$. The figures along the curves are hours (JST). 


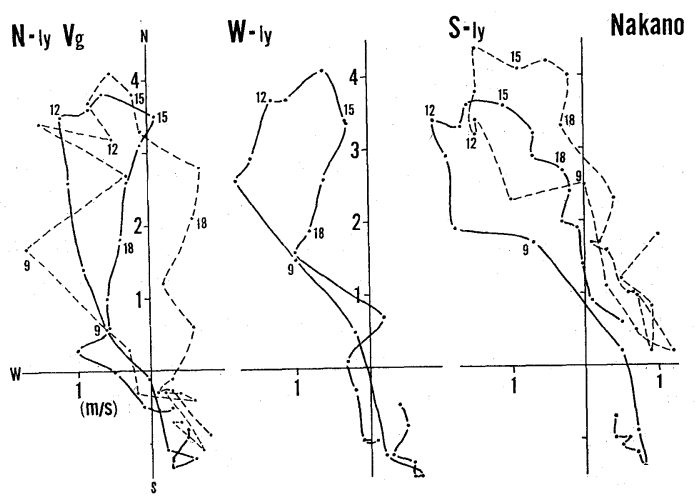

Fig. 8 Same as Fig. 7 except for Sendai area.
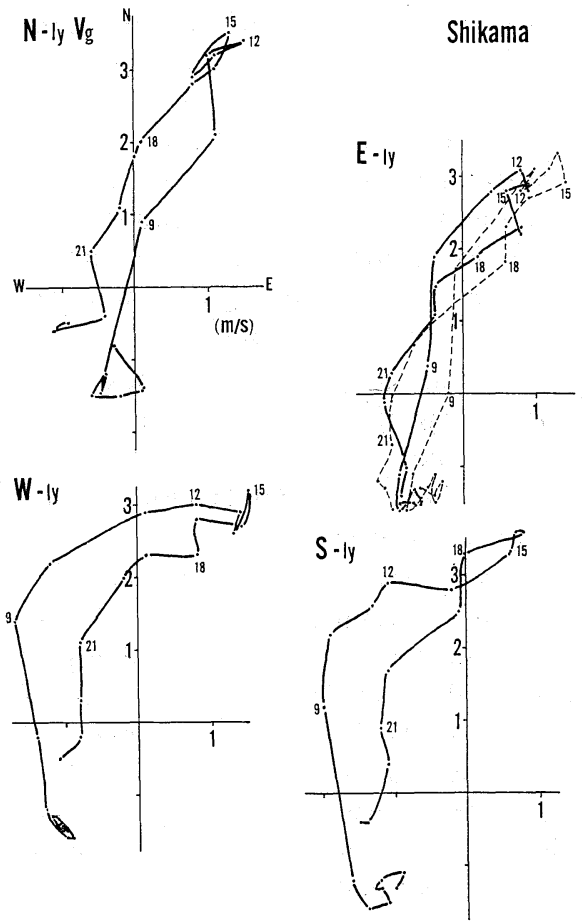

Fig. 9 Same as Fig. 7 except for Himeji area.

the fact that the days with westerly $V_{g}$ do not form a particular group as shown in Fig. 6(B).

Fig. 9 shows the hodographs for Himeji. The observing station Shikama is about $2 \mathrm{~km}$ inland though the coastline is not definite because of many projecting wharfs. Under the easterly $V_{g}$, which dominates more than half of the sea breeze days in this area, the surface wind varies nearly in a straight line. The northerly $V_{g}$ case is not so different from this, but the westerly component is noticeable during the morning hours, in contrast with the former case. On the contrary, under the southerly $V_{g}$ the hodograph removes to the west, namely to the low pressure side especially at the growing stage of the sea breeze. The westerly $V_{g}$ case is similar to the southerly one, so that we may state about them together that the southwesterly $V_{g}$ has an effect on the sea breeze to strengthen the southeasterly component.

\subsection{Land air temperature for the sea breeze occurrence}

The variances of the hodographs shown in the previous section could be caused not only by the pressure gradient but some other factors. If the pressure field had some correlation with the temperature field, the variance of the sea breeze patterns might have resulted from the latter rather than the pressure field itself. To clarify this uncertainty, in case of Akita, where the hodographs vary distinctly with the $V_{g}$ directions, the temperature data have been examined. The data belong to the Akita Local Meteorological Observatory, $1 \mathrm{~km}$ inland of the Yabase station. In Fig. 10 the seasonal variation of the characteristic temperatures on the sea breeze days is shown. This includes the days on which $Q_{A M}<$ 200 ly together with $\geqq 200$ ly. The temperature at $500 \mathrm{JST}$ is bounded under the reference curve. It seems according to some observations that this reference curve is not so far from the sea water temperature. The sea breeze starts when the temperature exceeds this curve. But even in the same season the sea breeze does not blow till the temperature rises, roughly speaking, by

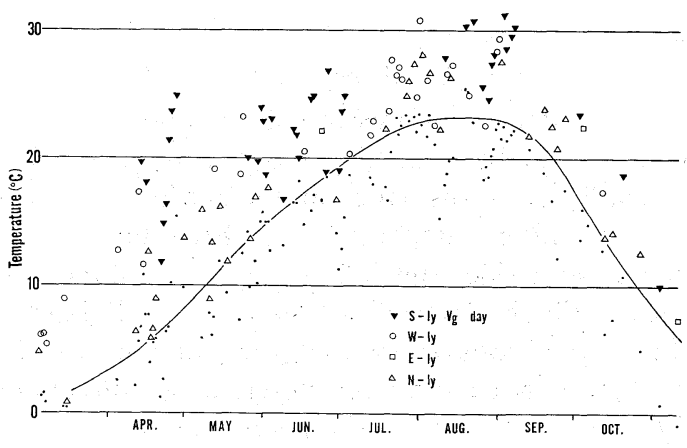

Fig. 10 Seasonal variation of the air temperature just before the sea breeze reached, with the temperature at 500 JST on the sea breeze days represented by small dots, at the Akita Observatory where the temperature was referred to only every one hour. 
$2-10^{\circ} \mathrm{C}$ higher under the southerly $V_{g}$ than under the northerly one. Therefore, it is not true that under the southerly $V_{g}$ the sea breeze starts later because of delayed temperature rise in the morning. This fact may demonstrates that the $V_{g}$ direction takes part in the sea breeze behavior independently though the most important factor for the sea breeze growth must be the differential heating of the land and sea air.

\section{Conclusions}

The effects of the general pressure gradient on the sea breeze growth have been investigated for three areas in Japan. The results for each area, possessing some discrepancies, may be summarized as follows. Suppose that the land heating is large enough, i.e. $Q_{A M} \geqq 200 \mathrm{ly}$.

i) When the $V_{g}$ direction is in accordance with the ordinary sea breeze direction in the area, the sea breeze occurs with high probability. Under an opposite $V_{g}$ often the sea breeze does not occur. Especially in Sendai, in case the $V_{g}$ speed exceeds about $10 \mathrm{~m} \mathrm{sec}^{-1}$ the probability of the sea breeze occurrence shows a notable difference according to the $V_{g}$ directions.

ii) The surface wind hodograph of the sea breeze days, taken an average separately for the $V_{g}$ directions, removes its position to the low pressure side respectively compared with the other $V_{g}$ direction cases. But the extent and fashion of the displacement is dependent on locality. For example, in Himeji a wind component down the pressure gradient is distinctly superposed on the normal sea breeze only during the morning hours. In Sendai the displacement of hodograph is also partial and less prominent.

The difference of hodograph between two ranks of $V_{g}$ speed is not clear in the same area and under the same $V_{g}$ direction.

iii) Under such pressure distribution that the high is on the sea, the sea breeze starts immediately after the land air temperature exceeds the sea water temperature. When the high is on the land side, the inflow of the sea breeze is delayed till the land air is heated $2-10^{\circ} \mathrm{C}$ higher. These conditions show that the variance of the sea breeze pattern under different $V_{g}$ directions is due to the very $V_{g}$ direction, not to the concerned temperature field. But this fact has not been confirmed for Sendai and Himeji area because no adequate data regarding the air and sea temperature were available there.

Generally speaking, i) and ii) coincide with the concluding remark in Section 1: under a moderate general wind the sea breeze appears with a fraction of the general wind added. But according to the present result, a wind down the pressure gradient rather than a fraction of $V_{g}$ is superposed on the sea breeze, and its magnitude is not sensitive to the $V_{g}$ speed. Among the above propositions i) states about the $V_{g}$ directions, while ii) and iii) state about the directions of the pressure gradient, different by $90^{\circ}$ from i). From the first the distribution of the $V_{g}$ is not uniform, but has a local feature as shown in Fig. 6. In addition, the analyses concerning ii) and iii) are on the basis of classification of the $V_{g}$ directions into only four groups. Therefore, the discrepancy of the $V_{g}$ directions in i) and ii), iii) is not a definite fact, or even they may possibly be the same direction. Similarly the difference between the directions of the superposed wind component affected by $V_{g}$ and $V_{g}$ itself cannot be exactly given. In order to make these clear, more collective data extending over a few years or for some other areas need to be analysed. Anyhow, such an index like Biggs and Graves' that does not take the $V_{g}$ direction into consideration has proved to be imperfect to separate the sea breeze days and non-sea breeze days.

The peculiar patterns of the sea breeze for each area suggest that the sea breeze is very sensitive to the locality. Each of the peculiar features has naturally some cause, but it is not the present subject.

The judging criteria for the sea breeze in this work is not necessarily sufficient. The aim of the present criteria is to select the day possessing sea breeze-like variation, followed by further analyses of the selected days, so that such days on which the sea breeze occurred with a more or less irregular pattern by some reason were not all selected. The definition of the sea breeze often includes a condition that a counter current layer exists above the surface sea breeze layer. This condition has been ignored in the present investigation. To be sure, there is room for discussion about the sea breeze when the $V_{g}$ direction is nearly the same as the ordinary sea breeze direction. In such a condition it can be calm, or even a land breeze appears, near the surface during the night when the atmosphere is stratified stably, and the onshore $V_{g}$ is observed during the day. Such a diurnal variation may be excluded from the sea breeze in the proper sense. From another point of view, however, it seems unreasonable to exclude them fundamentally because of the onshore $V_{g}$, since the onshore breeze 
appears in turn with the night calmness or the land breeze as a result of a regular variation of the land temperature. In this work they have been considered to be a sort of the sea breeze.

\section{Acknowledgements}

The author would like to express his thanks to the referees for helpful comments. $\mathrm{He}$ is indebted to the personnel of the local government offices and the meteorological observatories concerned for supplying useful data. He also thanks the staff of the FIP Co. for collecting and processing the greater part of the data.

\section{References}

Biggs, W. G. and M. E. Graves, 1962: A lake breeze index. J. Appl. Meteor., 1, 474-480.

Defant, F., 1951: Local winds. Compendium of meteorology. Amer. Meteor. Soc., 655-672.

Estoque, M. A., 1962: The sea breeze as a function of the prevailing synoptic situation. J. Atmos. Sci., 19, 224-250.
Haurwitz, B., 1947: Comments on the sea-breeze circulation. J. Meteor., 4, 1-8.

Kitabayashi, K., 1976: Statistical analyses of sea and land breeze characteristics using ground level wind data (in Japanese). Kogai, 11, 288306.

Lyons, W. A., 1972: The climatology and prediction of the Chicago lake breeze. J. Appl. Meteor., 11, 1259-1270.

Pielke, R. A., 1974: A three-dimensional numerical model of the sea breeze over south Florida. Mon. Wea. Rev., 102, 115-139.

Sahashi, K., 1978: On the land and sea breeze around Okayama area (in Japanese). Tenki, 25, 357-363.

Walsh, J.E., 1974: Sea breeze theory and applications. J. Atmos. Sci., 31, 2012-2026.

Wexler, R., 1946: Theory and observations of land and sea breezes. Bull. Amer. Meteor. Soc., 27, 272-287.

Yoshikado, H., 1978: The characteristics of the sea breeze in relation to the pressure field (in Japanese). Kogai, 13, 292-301.

\title{
海風の形態と外部気象条件の関係についての統計的解析
}

\author{
吉 門 洋 \\ 公害資源 研 究 所
}

海風の形態が日ごとに異なる点を総観スケールの気象条件，特に気圧傾度の向きと強さ，および海陸温度差の 一指標としての午前中積算日射量 $Q_{\mathrm{AM}}$ と結びつけて統計的に解析した。対象として秋田，仙台，姫路地域の 1 年間のデータを用いた。海風出現日を抽出するための判定には 6 時と 12 または 15 時の地上風向風速を用い，地域 ごとに基準範囲を設定した。

その結果, これらの地域における海風出現の熟的条件は $Q_{\mathrm{AM}} \geqq 200 \mathrm{ly}$ が一応の目安となるが, この条件を満な しても, 気圧傾度の向きによって海風出現率はかなり異なる。すなわち, 地衡風向がその地域の海風卓越風向々 一致するとき海風出現率はきわめて高く，逆の地衡風向では低い。また気圧傾度の向きによって，4方位別のグ ループで平均した海風出現日のホドグラフは，それぞれ他のグループのホドグラフに比べて低気圧側にかたよる 傾向がある。すなわち海風に対して低気圧に向から風が付加される。

このような結果は概略として従来の文献, 例えば Pielke（1974）の数值実験で特定の条件について示されてい た海風の特徵と合致しており，その特徵が広い条件下で統計的に出現することを示している。 